\title{
IDENTIFYING CRYPTIC SPECIATION ACROSS GROUNDWATER POPULATIONS: FIRST COI SEQUENCES OF BATHYNELLIDAE (CRUSTACEA, SYNCARIDA)
}

\author{
A. I. Camacho*1, B. A. Dorda** \& I. Rey**
}

\section{SUMMARY}

A. I. Camacho, B. A. Dorda \& I. Rey. 2011. Identifying cryptic speciation across groundwater populations: first $\mathrm{COI}$ sequences of Bathynellidae (Crustacea, Syncarida). Graellsia, 67(1): 7-12.

The biodiversity of groundwater fauna remains poorly known and understood. Groundwater biodiversity studies are strongly affected by habitat inaccessibility and taxonomic crisis. The objective of this work was to investigate levels of genetic divergence across populations of Bathynellacea, a small crustacean group that lives exclusively in groundwater, in order to evaluate the extent of cryptic speciation in morphologically constrained clades. Partial sequences of cytochrome oxidase I (COI) have been obtained, for the first time in Bathynellidae. Specimens analyzed of the genus Vejdovskybathynella were obtained from six populations morphologically assignable to a single species; all of them are located in different areas of one of the largest karst systems (110 km of galleries topographied) known in Spain. The analyses of molecular data demonstrate the presence of three highly divergent genetic units, possibly corresponding to undescribed new species. The results of this study provide the first molecular data that complement morphological knowledge in order to address phylogenetic studies to try to resolve the relations between genera and species of the Bathynellidae family. We conclude that the evolutionary scenario of this special group of subterranean crustaceans cannot be revealed only by using morphological information due to the presence of very old lineages of cryptic species, as has been brought to light with the molecular data obtained here.

Keywords: groundwater fauna; COI; cryptic species; Bathynellacea; Spain.

\section{RESUMEN}

A. I. Camacho, B. A. Dorda \& I. Rey. 2011. Divergencia genética en especies cripticas de agua subterránea: primeras secuencias COI obtenidas de la familia Bathynellidae (Crustacea, Syncarida, Bathynellacea). Grael/sia, 67(1): 7-12 (en inglés).

La biodiversidad de la fauna de las aguas subterráneas sigue siendo poco conocida. Los estudios de diversidad biológica de las aguas subterráneas se ven negativamente afectados por la inaccesibilidad del hábitat y la crisis taxonómica. El objetivo de este trabajo es estudiar los niveles de divergencia genética de poblaciones de Bathynellacea, un pequeño grupo de crustáceos que viven exclusivamente en las aguas subterráneas, para evaluar la extensión de

* Museo Nacional de Ciencias Naturales (CSIC), Department of Biodiversity and Evolutionary Biology, Madrid, Spain. E-mail: mcnac22@mncn.csic.es

** Museo Nacional de Ciencias Naturales (CSIC), Department of Collections, Tissues and DNA Collection, Madrid, Spain.

1 Corresponding author 


\begin{abstract}
la especiación críptica en clados morfológicamente constreñidos. Las secuencias parciales de citocromo oxidasa I (COI) se han obtenido, por primera vez, de varios ejemplares de la familia Bathynellidae. Los ejemplares analizados del género Vejdovskybathynella proceden de seis poblaciones, morfológicamente asignables a una única especie, de uno de los sistemas kársticos más grandes de España (110 km de galerías topografiadas). El análisis de datos moleculares demuestra la presencia de tres unidades con elevada divergencia genética, dos de ellas posiblemente correspondientes a nuevas especies sin describir. Los resultados de este estudio proporcionan los primeros datos moleculares que permiten complementar el conocimiento morfológico para abordar estudios filogenéticos que ayuden a resolver las relaciones de parentesco de las especies de diferentes géneros de la familia Bathynellidae. Podemos concluir que el escenario evolutivo de este grupo de crustáceos subterráneos no se puede revelar sólo con información morfológica debido a la presencia de linajes muy antiguos de especies crípticas que parecen salir a la luz sólo con datos moleculares como los obtenidos en este trabajo.
\end{abstract}

Palabras clave: fauna acuática subterránea; COI; especies cripticas; Bathynellacea; España.

\section{Introduction}

In stygobitic crustaceans, the underestimation of species diversity based on morphological characters has been recently highlighted (Proudlove \& Wood, 2003) by a number of studies using DNA sequence data in which cryptic species have been identified (Jarman \& Elliot, 2000; Finston \& Johnson, 2004; Lefébure et al.,, 2006; Guzik et al., 2008; Trontelj et al., 2009). Prediction of species diversity and boundaries with DNA sequence data are being increasingly investigated, particularly with the advent of DNA barcoding (Hebert et al., 2003).

In subterranean fauna, the convergent evolution of morphological characters that are associated with adaptations to this environment (Jones et al., 1992; Kane et al., 1994) confounds their true phyletic descent through the retention of primitive traits and loss of complex features (Guzik et al., 2008). The isolation and strong selective pressures inherent to the adoption of an underground life can lead in polar opposite directions, resulting in both high genetic divergence and morphological convergence (Finston et al., 2007), which can greatly confound phylogenetic interpretation (Lefebure et al., 2006, Lefebure et al., 2007). Morphological simplification is extreme in Bathynellacea as a consequence of progenetic development (Schminke, 1981), an evolutionary scenario seemingly common in meiofauna (Westheide, 1987).

Given the fact that, in some cases, morphology is not sufficient to identify closely related species, one step that now appears necessary to conduct evolutionary studies in Bathynellacea is to obtain DNA sequences in different species for comparison. In this paper we report that for the first time we have obtained sequences of mitochondrial DNA (mtDNA) cytochrome c oxidase I (COI) from Bathynellidae. These first molecular successes are relevant, because it is highly difficult to obtain and amplify DNA of these rare, tiny crustaceans, which are hard to find, very fragile once collected, and live with many fungi that interfere with the DNA extractions.

The mtDNA gene COI allowed us to identify divergent mtDNA clades that may represent very old lineages and cryptic species. This has revealed the likely existence of three species, of the genus Vejdovskybathynella Serban and Leclerc, 1984, two of them new, which morphologically had been previously identified as a single species. Clear definitions and demarcation of species using genetic divergences still require further research (Hajibabaei et al., 2006; Costa et al., 2007), but these results suggest that the use of barcoding (molecular mtDNA data) in this group can be a useful and complementary technique to morphological taxonomy in order to find cryptic species overlooked by traditional taxonomic methods (Burns et al., 2007).

\section{Materials and Methods}

\section{TAXON SAMPLING}

The samples used in the extraction of DNA for this study come from 12 specimens of Bathynellidae belonging to the genus Vejdovskybathynella (see Table 1). These specimens represent five populations of the main cave of the Ojo Guareña karst system (OG01, OG09, OG16, Huesos and Erizos river), plus one associated cave (Redonda cave).

For collecting, we used hand plankton nets (mesh size $0.100 \mathrm{~mm}$ ) to filter the water of the 


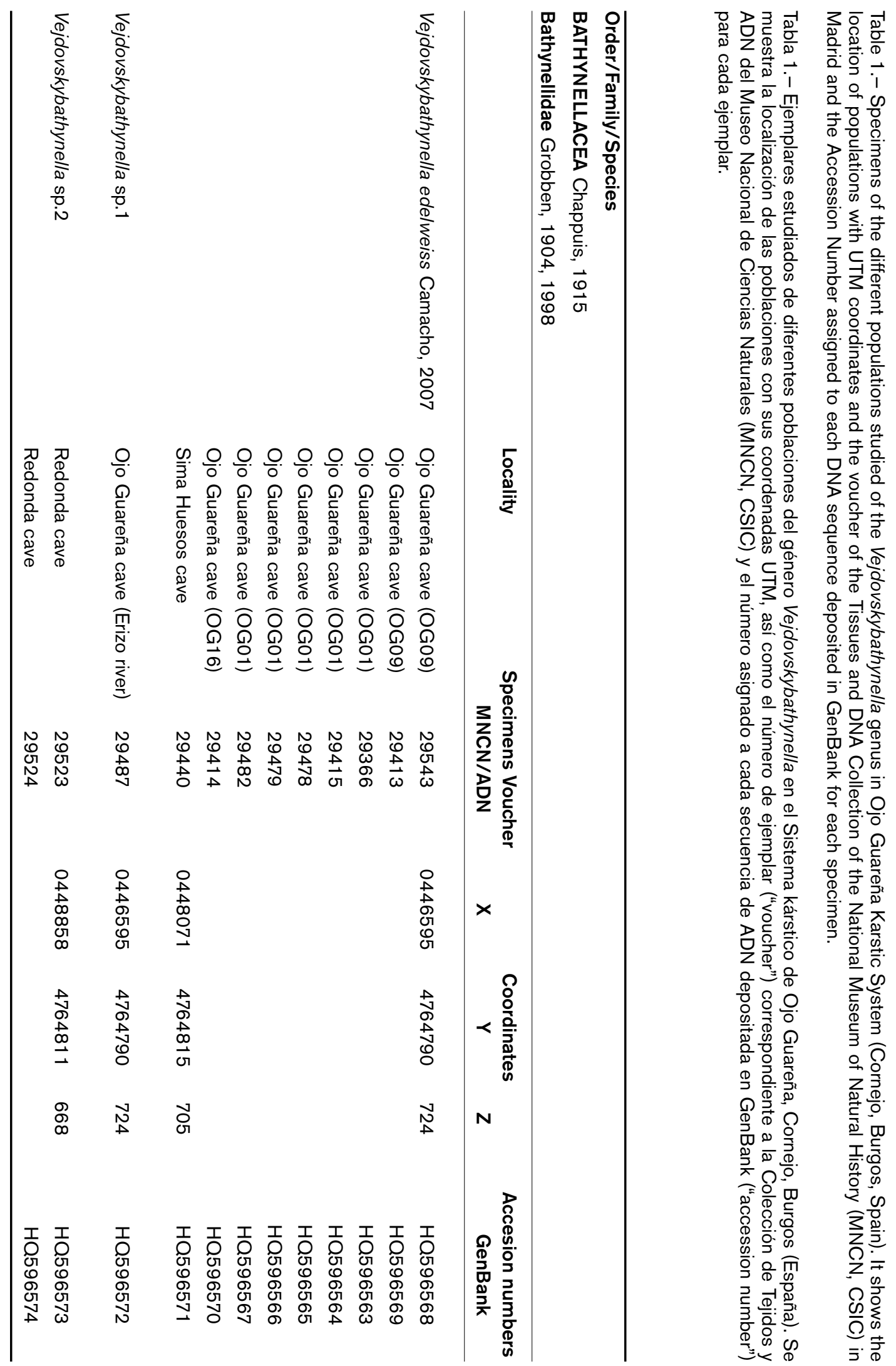


Table 2.- COI genetic distances (\%) between populations and species of the genus Vejdovskybathynella in the Ojo Guareña Karstic System (Burgos, Spain).

Tabla 2.- Distancias géneticas, secuencias COI, en \% entre las poblaciones y especies del género Vejdovskybathynella estudiadas en el Sistema kárstico de Ojo Guareña, Burgos (España).

\begin{tabular}{lcccccc}
\hline Populations & OG01 & OG09 & OG16 & Huesos cave & Erizos river & Redonda cave \\
\hline OG01 & $0-1.6$ & $0.2-1.8$ & $0.2-1.4$ & $1.2-2$ & 15 & $14-15$ \\
OG09 & - & 0.8 & 0.4 & $0.6-1.4$ & $15-16$ & $13-14$ \\
OG16 & - & - & - & 1 & 15 & 14 \\
Huesos cave & - & - & - & - & - & 14 \\
Erizos river & - & - & - & - & - & $16-17$ \\
Redonda cave & - & - & - &
\end{tabular}

pools and gours of the cave epikarstic zone, and Karaman-Chappuis methods to filter the interstitial water of Erizos subterranean river (as in Camacho, 1992).

DNA EXTRACTION, AmPLIFICATION AND SEQUENCING Extraction was carried out with Chelex following Walsh et al., (1991). A 510 base pair (bp) region of the COI gene was amplified with the primers C1-J-1718 (5'-GGAGGATTTGGAAATTGATTAGTTCC- 3') and HCO2198 (5'-TAAACTTCAGGGTGACCAAAAAATCA-3') (Folmer et al., 1994, Simon et al., 1994). Three $\mathrm{ml}$ of the DNA solution were used as a template. $1 \mathrm{x}$ of the corresponding buffer (with $2 \mathrm{mM}$ $\left.\mathrm{MgCl}_{2}\right), 10 \mathrm{mM}$ dNTPs mix, $0.1 \mathrm{mM}$ of both primers, $0.02 \%$ BSA, and 0.125 units AmpliTaq Gold ${ }^{\circledR}$ DNA Polymerase (Applied Biosystems). PCR products were purified by treatment with ExoSAP-IT (USB Amersham, Buckinghamshire, UK). The purified PCR product was used to sequence in both directions using the BigDye Terminator v3.1 sequencing kit (Applied Biosystems Inc., Foster City, USA). The amplified DNA was sequenced in an ABI 3730 genetic analyser (Applied Biosystems).

Nucleotide sequence composition statistics were estimated using PAUP* 4.0b10 (Swofford, 2002). Sequence divergence was calculated using "uncorrected ("p")" distance matrix and also corrected distance using the evolutive substitution model $(\mathrm{GTR}+\mathrm{G}+\mathrm{I})$ (Lanave et al., 1984), and the Kimura-2-parameter model (Swofford, 2002) (Table 2). All sequences were submitted to GenBank (see Table 1) and the extracted DNA was deposited in the Tissues and DNA Colletion of the MNCN.

\section{Results}

No stop codons or gaps were observed in any of the translated amino acid sequences suggesting that the genuine mtDNA COI gene was sequenced. The alignment of 12 COI gene sequences resulted in a consensus length of $510 \mathrm{bp}$, of which $60 \%$ were variable.

Samples analyzed clustered in three genetically distinct lineages comprising the six populations: one known, Vejdovskybathynella edelweiss Camacho, 2007 (found in four populations, OG01, OG09, OG16 and Huesos), and two probably new species found in Erizos river and Redonda cave.

Genetic distance found between specimens of Vejdovskybathynella edelweiss studied from the same population (OG01) is $1.6 \%$, and between populations of the main cave $2 \%$ (OG01 and Huesos) (Table 2). The specimens from the Erizos river, with a genetic distance of $15 \%-17 \%$ from other populations, probably represent a new species, $V$. sp. 1. The same goes for Redonda Cave specimens, that we consider a species possibly different from $V$. edelweiss and $V$. sp. 1, with which it shows genetic distances of $13 \%-15 \%$ and $16 \%$ $17 \%$ respectively.

\section{Discussion and Conclusions}

Cryptic species have also been identified using molecular methods in other subterranean taxa such as, for example, amphipods (Finston et al., 2007), Parabathynellidae (Guzik et al., 2008), and others. All these species discovered with molecular methods can help to define species boundaries and fos- 
ter further, targeted morphological studies, which can lead to the discovery of new morphological characters (Moritz \& Cicero, 2004).

Currently, it is not clear what level of divergence designates a significant difference within and between lineages and some authors employ a 2-3\% threshold (Hebert et al., 2003; Meyer \& Paulay, 2005; Meier et al., 2008; Foley et al., 2007). Hajibabaei et al. (2006) suggested that 4.5-6.0\% divergence in COI mtDNA sequences is enough to discriminate between congeneric species in Lepidoptera. Conversely, Lefébure et al. (2006) investigated the relationship between morphospecies and genetically diverse species and identified $16 \%$ genetic divergence to be a consistent indicator of distinct species among the crustacean groups they examined. Accepting this treshold as valid, the high values of divergence found by us (between 14 and $17 \%$ ) allows us to think that we have discovered two cryptic species, Vejdovskybathynella sp. 1 and sp. 2, which until now had remained unidentified by morphological analysis. We can expect that the large divergences found among our populations are an indicative of a long-term isolation between them. The time elapsed will depend on the mutation rate of the gene for this particular group of species, but these results suggest nevertheless a lack of genetic flow between the populations that could have been caused by physical isolation between populations due to habitat fragmentation and lack of dispersal mechanisms (e.g., lack of free-swimming larvae) (Camacho et al., 2006).

Cryptic species are commonly defined as species indistinguishable by morphology, and the morphological characters commonly used for this group in classic taxonomy do not provide any solution to explain the divergences revealed by the molecular data. Furthermore, the mtDNA COI differences observed cannot assure us that there are species differentiation while the gene substitution rate remains unknown for this group. Thus it would be desirable to include further mitochondrial genes and nuclear genes in future molecular analyses to improve the definition of the species boundaries.

In addition to this, morphological taxonomy will remain an essential element in biodiversity assessments, so the identification of cryptic species through molecular techniques will only be useful here if these findings are later translated into the identification of new morphological, ethological or ecological discrimination characters that are not masked by convergence, and allow for the identification of morphotypes. Only the combined use of morphological and molecular characters will make it possible to have an aproximate idea of the true relationships between the different species of Bathynellidae, and will allow tackling the evolutionary history of the group with the correct perspective.

\section{Acknowledgements}

We gratefully acknowledge C. Puch, M. García-París, D. Buckley and X. Eekhout, who helped us in different ways. This work was supported by project CGL2010-15786 MICINN.

\section{References}

Burns, J. M., Janzen, D. H., Hajibabaei, M., Hallwachs, W. \& Hebert, P. D. N., 2007. DNA barcodes of closely related (but morphologically and ecologically distinct) species of skipper butterflies (Hesperiidae) can differ by only one to three nucleotides. Journal of the Lepidopterists Society, 61: 138-153.

Camacho, A. I., 1992. Sampling the subterranean biota. Cave (aquatic environment). In: A. I. Camacho (ed.), The Natural History of Biospeology. Monografías del Museo Nacional de Ciencias Naturales, 7. Madrid: 135-168.

Camacho, A. I., Torres, T., Puch, C. J., Ortiz, J. E. \& Valdecasas, A. G., 2006. Small-scale biogeographical patterns in some groundwater Crustacea, the syncarid, Parabathynellidae. Biodiversity and conservation, 15(11): 3527-3541.

Costa, F. O., de Waard, J. R., Boutillier, J., Ratnasingham, S., Dooh, R. T., Hajibabaei, M. \& Hebert, P. D. N., 2007. Biological identifications through barcodes: the case of the Crustacea. Canadian Journal of Fisheries and Aquatic Sciences, 64: 272-295. doi:10.1139/F07008

Finston, T. L. \& Johnson, M. S., 2004. Geographic patterns of genetic diversity in subterranean amphipods of the Pilbara, Western Australia. Marine and Freshwater Research, 55: 619-628. doi:10.1071/MF04033

Finston, T. L., Johnson, M. S., Humphreys, W. F., Eberhard, S. M. \& Halse, S. A., 2007. Cryptic speciation in two widespread subterranean amphipod genera reflects historical drainage patterns in an ancient landscape. Molecular Ecology, 16: 355-365. doi: 10.1111/j.1365-294X.2006.03123.X

Foley, D. H., Wilkerson, R. C., Cooper, R. D., Volovsek, M. E. \& Bryan, J. H., 2007. A molecular phylogeny of Anopheles annulipes (Diptera: Culicidae) sensu lato: the most species-rich anopheline complex. Molecular Phylogenetics and Evolution, 43: 283297. doi:10.1016/j.ympev.2006.10.008 
Folmer, O., Black, M., Hoeh, W., Lutz, R. \& Vrijenoek, R.., 1994. DNA primers for amplification of mitochondrial cytochrome c oxidase subunit 1 from diverse metazoan invertebrates. Molecular Marine Biology and Biotechnology, 3: 294-299.

Guzik, M. T., Abrams, K. M., Cooper, S. J. B., Humphreys, W. F., Cho, J.-L. \& Austin, A., 2008. Phylogeography of the ancient Parabathynellidae (Crustacea, Bathynellacea) from the Yilgara region of Western Australia. Invertebrate Systematics, 22(2): 205-216. doi:10.1071/ IS07040

Hajibabaei, M., Janzen, D. H., Burns, J. M., Hallwachs, W. \& Herbert, P. D. N., 2006. DNA barcodes distinguish species of tropical Lepidoptera. Proceedings of the National Academy of Science of the United States of America, 103: 968-971. doi: 10.1073/pnas.0510466103

Hebert, P. D., Cywinska, A., Ball, S. L. \& deWaard, J. R., 2003. Biological identifications through DNA barcodes. Proceedings of the Royal Society of London, $B$ 270: 313-321. doi: 10.1098/rspb.2002.2218

Jarman, S. N. \& Elliot, N. G., 2000. DNA evidence for morphological and cryptic Cenozoic speciations in the Anaspididae, "living fossils" from the Triassic. Journal of Evolutionary Biology, 13: 624-633. doi: 10.1046/j.1420-9101.2000.00207.x

Jones, R., Culver, D. C. \& Kane, T. C., 1992. Are parallel morphologies of cave organisms the result of similar selection pressures? Evolution, 46: 353-365.

Kane, T. C., Culver, D. C. \& Mathieu, J., 1994. Biotic fluxes and gene flow. In: J. Gibert, D. L. Danielopol \& J. Stanford (eds). Groundwater ecology. Academic Press: New York: 245-259.

Lanave, C., 1984. A new method for calculating evolutionary substitution rates. Journal of Molecular Evolution, 20: 86-93.

Lefébure, T., Douady, C. J., Gouy, M., Trontelj, P., Briolay, J. \& Gibert, J., 2006. Phylogeography of a subterranean amphipod reveals cryptic diversity and dynamic evolution in extreme environments. Molecular Ecology, 15: 1797-1806. doi:10.1111/j.1365-294X.2006.02888.x

Lefébure, T., Douady, C. J., Malard, F. \& Gibert, J., 2007. Testing vicariance and cryptic diversity in a widely distributed groundwater amphipod (Niphargus rhenorhodanensis). Molecular Phylogenetics and Evolution, 42: 676-686. doi:10.1016/j.ympev.2006.08.020

Meyer, C. P. \& Paulay, G., 2005. DNA barcoding: error rates based on comprehensive sampling. PLoS Biology, 3: e422. doi:10.1371/journal.pbio.0030422

Meier, R., Zhang, G. \& Ali, F., 2008. The use of mean instead of smallest interspecific distances exaggerates the size of the "barcoding gap" and leads to misidentification. Systematic Biology, 57: 809-813. doi: $10.1080 / 10635150802406343$
Moritz, C. \& Cicero, C., 2004. DNA barcoding: promise and pitfalls. PLoS Biology, 2: e354. doi:10.1371/journal.pbio.0020354

Proudlove, G. \& Wood, P. J., 2003. The blind leading the blind: cryptic subterranean species and DNA taxonomy. Trends in Ecology and Evolution, 18: 272-273. doi:10.1016/S0169-5347(03)00095-8

Trontelj, P., Douad, J. C., Fisher, C., Gibert, J., Goricki, S., Lefébure, T., Sket, B. \& Zaksek, V., 2009. A molecular test for cryptic diversity in ground water: how large are the ranges of macrostygobionts? Freshwater Biology, 54: 727-744. DOI: 10.1111/j.1365-2427.2007.01877.x

Schminke, H. K., 1981. Adaptations of Bathynellacea (Crustacea, Syncarida) to life in the interstitial ("Zoea theory"). Internationale Revue der gesamten Hydrobiologie und Hydrographie, 66: 578-637. doi: 10.1002/iroh.19810660411

Simon, C. 1., Frati, F., Beckenbach, A., Crespi, B., Liu, H., \& Flook, P., 1994. Evolution, weighting, and phylogenetic utility of mitochondrial gene sequences and a compilation of conserved PCR primers. Annals of the Entomological Society of America, 87: 51-701

Swofford, D. L., 2002. PAUP*: Phylogeny Analysis Using Parsimony (*and other methods), version 4.069. Sinauer Associates Inc., Sunderland, Massachusetts.

Walsh, P., Metzger, D. \& Higuchi, R.,1991. Chelex 100 as a medium for simple extraction of DNA for PCRbased typing from forensic material. Biotechniques, 10: 506-513.

Westheide, W., 1987. Progenesis as a principle in meiofauna evolution. Journal of Natural History, 21: 843854. doi: 10.1080/00222938700770501

Recibido / Received, 30-11-2010 Aceptado / Accepted, 16-02-2011 Publicado en línea / Published online, 8-03-2011 Publicado impreso / Published in print, 30-06-2011 